\title{
UJI EFEKTIVITAS ANTI BAKTERI EKSTRAK DAUN JAMBU BIJI LOKAL (PSIDIUM GUAJAVA L) TERHADAP PERTUMBUHAN STAPHYLOCOCCUS AUREUS DAN BACILUS SUBTILIS SECARA IN VITRO
}

\author{
Lia Yulisma ${ }^{1)}$ \\ ${ }^{1}$ Dosen Program Studi Pendidikan Biologi FKIP, Universitas Galuh Ciamis \\ Email: goli_yulisma31@yahoo.co.id
}
APA Citation: Yulisma, L. (2018). Uji Efektivitas Anti bakteri Ekstrak Daun Jambu Biji Lokal (Psidium Guajava L) Terhadap Pertumbuhan Staphylococcus Aureus Dan Bacilus Subtilis Secara In Vitro. Quagga: Jurnal Pendidikan dan Biologi, 10(2), 1-5. doi: 10.25134/quagga.v10i2.1296.

Received: 20-07-2018

Accepted: 27-07-2018

Published: 30-07-2018

\begin{abstract}
Abstrak: Penyakit infeksi merupakan penyakit yang banyak diderita masyarakat Indonesia. Diare dapat disebabkan oleh infeksi bakteri pada saluran pencernaan. Salah satu penanganan diare secara tradisional menggunakan antibakteri alternatif alami dari tumbuhan dengan. ambu biji (Psidium guajava) yang diduga bersifat antibiotik. Penelitian ini bertujuan mengetahui efektivitas antibakteri ekstrak daun jambu biji lokal dalam menghambat pertumbuhan bakteri patogen saluran pencernaan (Staphylococcus aureus, Bacilus subtilis) secara in vitro. Metode penelitian adalah eksperimen laboratorium dengan Rancangan Acak Lengkap (RAL). Analisis data menggunakan Hasil penelitian diameter zona hambat terbesar dari ekstrak etanol daun jambu biji lokal terhadap pertumbuhan bakteri Staphylococcus aureus pada konsentrasi $50 \mathrm{mg} / \mathrm{ml}$ dengan rata-rata 18,5 $\mathrm{mm}$ sedang diameter zona hambat terbesar pertumbuhan bakteri Bacilus subtilis padakonsentrasi $60 \mathrm{mg} / \mathrm{ml}$ dengan rata-rata diameter 23,5 $\mathrm{mm}$.
\end{abstract}

Kata Kunci : Antibakteri, Ekstrak Daun Jambu Biji Lokal, Staphylococcus aureus, Bacilus subtilis

\begin{abstract}
Infectious disease is a disease that affects many Indonesian people. Diarrhea can be caused by bacterial infections of the digestive tract. One treatment for diarrhea traditionally uses natural antibacterial alternatives from plants with. ambu seeds (Psidium guajava) which are thought to be antibiotic. This study aims to determine the antibacterial effectiveness of local guava leaf extract in inhibiting the growth of gastrointestinal pathogenic bacteria (Staphylococcus aureus, Bacilus subtilis) in vitro. The research method is a laboratory experiment with Completely Randomized Design (CRD). Data analysis using the results of the study The largest inhibitory zone diameter of the local guava leaf ethanol extract on the growth of Staphylococcus aureus bacteria at a concentration of $50 \mathrm{mg} / \mathrm{ml}$ with an average of $18.5 \mathrm{~mm}$ medium zone the biggest inhibition of growth of Bacilus subtilis bacteria at aconcentration of $60 \mathrm{mg} / \mathrm{ml}$ with an average diameter of $23.5 \mathrm{~mm}$.
\end{abstract}

Keywords : Antibacterial, Local Guava Leaf Extract, Staphylococcus aureus, Bacilus subtilis

\section{PENDAHULUAN}

Penyakit infeksi merupakan penyakit yang masih banyak diderita masyarakat Indonesia. Diare merupakan penyakit infeksi pada saluran pencernaan yang dapat disebabkan oleh infeksi maupun non infeksi. Menurut Thielman dan Guerrant et al., (2004) penyebab diare yang terbanyak adalah infeksi. Diare infeksi dapat disebabkan oleh virus, bakteri, dan parasit. Menurut Tjaniadi et al., (2003) kasus diare di Indonesia lebih sering disebabkan oleh Vibrio cholerae, Shigella spp, Staphylococcus aureus, Bacillus sp, Salmonella spp, Parahaemoliticus, Salmonella typhi, Escherichia coli, Campylobacter jejuni, dan Salmonella paratyphi.

Diare dapat ditanggulangi dengan menggunakan antibiotik. Penggunaan antibiotik yang tidak rasional dapat menyebabkan resistensi bakteri dan berdampak negatif terhadap lingkungan dan manusia. Adanya fenomena ini mendorong pencarian solusi yang terbaik bagi kesehatan. sebagai alternatif pengganti antibakteri sintetis yang dapat diperoleh dari tanaman (Cowan, 1999).

Masyarakat luas beranggapan bahwa penggunaan obat tradisional lebih aman dibandingkan dengan obat kimia sehingga mereka lebih suka menggunakan obat tradisional untuk menyembuhkan penyakitnya. Penggunaan obat tradisional jika kurang tepat dapat mengakibatkan efek samping yang merugikan. Kurangnya informasi tentang obat tradisional oleh masyarakat merupakan salah satu kendala dalam penggunaan obat tradisional sehingga 
penggunaannya menjadi kurang optimal (Hembing, 1992).

Senyawa metabolit sekunder tanaman digunakan sebagai obat tradisional karena mengandung bahan antibakteri dan pengawet alami (Mittal et al., 2010). Penemuan berbagai senyawa obat baru dari bahan alam semakin memperjelas peran penting metabolit sekunder tanaman sebagai sumber bahan baku obat. Metabolit sekunder adalah senyawa hasil sintesis dari metabolit primer. Metabolit sekunder umumnya dihasilkan oleh tumbuhan tingkat tinggi, yang bukan merupakan senyawa penentu kelangsungan hidup secara langsung, tetapi lebih sebagai hasil mekanisme pertahanan diri organisma. Kandungan senyawa metabolit sekunder yang berfungsi sebagai antikanker, antibakteri dan antioksidan adalah senyawa golongan alkaloid, tanin, golongan polifenol dan turunannya (Mittal et al., 2010).

Jambu biji ( $P$. guajava) merupakan salah satu tanaman obat yang sudah banyak dimanfaatkan dalam pengobatan tradisional. Menurut Adnyana et al., (2004) daun jambu biji ( $P$. guajava) bersifat antibiotik dan telah dimanfaatkan untuk anti diare. Beberapa penelitian yang telah dilakukan membuktikan bahwa daun jambu biji mengandung beberapa senyawa fitokimia yang dapat dimanfaatkan untuk mencegah dan mengobati suatu penyakit, karena daun jambu biji banyak mengandung antioksidan, anti diare dan anti-virus DBD (Demam Berdarah Dengue) (Mittal et al., 2010).

Buah jambu biji mengandung asam amino (triptofan, lisin), pektin, kalsium, fosfor, besi, mangan, magnesium, belerang dan vitamin (A, B1 dan C). Buah jambu yang menjelang matang, mengandung vitamin $\mathrm{C}$ sebanyak 3-6 kali lipat lebih tinggi dari jeruk. Jambu biji mengandung serat tinggi yang larut dalam air, terutama dibagian kulitnya sehingga dapat mengganggu penyerapan glukosa dan lemak yang berasal dari makanan dan membuangnya ke luar tubuh. Buah jambu biji mengandung banyak vitamin dan serat, sehingga sangat cocok sekali dikonsumsi untuk menjaga kesehatan. Jambu biji yang banyak dijumpai di Indonesia memiliki daging buah berwarna merah dan putih (Lanawati, 2003).

Selain pada buahnya, daun jambu biji juga memiliki senyawa fitokimia yang berpotensi sebagai obat. Beberapa penelitian menemukan bahwa kandungan utama daun jambu adalah zat tanin (terutama daun yang masih muda), dan minyak atsiri dengan komponen penyusunnya adalah $\alpha$-pinene, $\beta$-pinene, limonene, mentol, terpenyl asetat, isopropyl alkohol, longicyclene, caryophyllene, $\quad \beta$-bisabolene, $\quad$ oksida caryophyllene, $\beta$-copanene, farnesene, humulene, selinene, cardinene dan curcumene (Nisha et al., 2011).

Penelitian ini bertujuan mengetahui aktivitas antibakteri dan konsentrasi hambat minimum ekstrak daun jambu biji lokal. Diharapkan hasil penelitian ini dapat memberikan informasi ilmiah tentang aktivitas antibakteri daun jambu biji.

\section{METODOLOGI PENELITIAN}

Metode penelitian yang digunakan adalah eksperimental laboratorium. Disain menggunakan Rancangan Acak Lengkap (RAL) pola faktorial dengan 7 perlakuan $(5 \mathrm{mg} / \mathrm{ml}, 10$ $\mathrm{mg} / \mathrm{ml}, 20 \mathrm{mg} / \mathrm{ml}, 30 \mathrm{mg} / \mathrm{ml}, 40 \mathrm{mg} / \mathrm{ml}, 50$ $\mathrm{mg} / \mathrm{ml}, 60 \mathrm{mg} / \mathrm{ml}$ ) dan 3 kali ulangan. Variabel bebas berupa variasi konsentrasi ekstrak daun jambu biji (Psidium guajava), sedang variabel tergantung adalah uji antibakteri terhadap bakteri patogen saluran pencernaan (Staphyloccocus aureus, Bacilus subtilis).

Data dianalisis menggunakan analisis ragam (ANOVA) pada tingkat kepercayaan 95\%. Jika terdapat beda nyata, dilanjutkan dengan uji jarak ganda Duncan (Duncan's New Multiple Range Test) pada tingkat kepercayaan yang sama (Gomez, 1995).

\section{HASIL DAN PEMBAHASAN}

Sebelum dilakukan uji antibakteri terlebih dahulu dilakukan uji fitokimia pada daun jambu biji. Uji fitokimia ekstrak daun jambu biji $(P$. guajava) menggunakan analisis kimia dengan mengamati perubahan warna pada ekstrak. Analisis ini sangat berguna untuk menentukan golongan utama senyawa aktif dari ekstrak daun jambu biji yang memiliki aktivitas antibakteri. Dari hasil uji fitokimia dapat diketahui bahwa ekstrak etanol daun jambu biji mengandung flavonoid, alkaloid, polifenol, dan tanin.

Tabel 1. Diameter zona hambat uji antibakteri ekstrak daun Jambu Biji Lokal terhadap bakteri S. aureus

\begin{tabular}{ccccccc}
\hline & $(\mathrm{K})$ & \multicolumn{5}{c}{ Jambu Biji } \\
\cline { 3 - 7 } $\mathrm{T}$ & $\mathrm{mg} /$ & \multicolumn{5}{c}{ Diameter Zona Hambat (mm) } \\
\cline { 3 - 7 } & $\mathrm{ml}$ & $\mathrm{U} 1$ & $\mathrm{U} 2$ & $\mathrm{U} 3$ & $\mathrm{JP}$ & $\mathrm{RP}$ \\
\hline $\mathrm{A}$ & 5 & 0 & 0 & 0 & 0 & 0 \\
\hline $\mathrm{B}$ & 10 & 0 & 0 & 0 & 0 & 0 \\
\hline $\mathrm{C}$ & 20 & 13,5 & 14,5 & 14,3 & 42,3 & 14,1 \\
\hline $\mathrm{D}$ & 30 & 15,7 & 15,7 & 15,7 & 47,1 & 15,7 \\
\hline $\mathrm{E}$ & 40 & 17,9 & 18,2 & 18,3 & 54,4 & 18,1 \\
\hline $\mathrm{F}$ & 50 & 18,2 & 18,8 & 18,5 & 55,5 & 18,5 \\
\hline
\end{tabular}


Quagga: Jurnal Pendidikan dan Biologi

Volume 10, Nomor 2, Juli 2018

\begin{tabular}{ccccccc}
\hline G & 60 & 17,7 & 15,7 & 15,1 & 48,5 & 16,2 \\
\hline \multicolumn{3}{c}{ JU } & & & & 247,8 \\
\hline RU & & & & & 11,8 \\
\hline
\end{tabular}

Keterangan :

JU : Jumlah umum

RU: Rataan umum

$\mathrm{T}$ : Perlakuan

$\mathrm{K}$ : Konsentrasi

U1 : Ulangan 1

U2 : Ulangan 2

U3 : Ulangan 3

JP : Jumlah perlakuan

RP : Rataan perlakuan

Uji anti bakteri ekstrak etanol daun jambu biji lokal menunjukan hasil yang berbeda-beda untuk setiap bekteri. Diameter zona hambat terbesar terhadap bakteri $S$. aureus adalah perlakuan ekstrak daun jambu biji dengan konsentrasi $50 \mathrm{mg} / \mathrm{ml}$ dengan nilai rata-rata diameter $18,5 \mathrm{~mm}$. Rerata diameter zona hambat ekstrak etanol daun jambu biji lokal adalah 11,8 $\mathrm{mm}$. Hasil diameter zona hambat uji antibakteri ekstrak etanol terhadap bakteri S. aureus dapat dilihat pada Tabel 1.

Terdapat kecenderungan bahwa konsentrasi yang berbeda pada ekstrak etanol daun jambu biji lokal memberikan pengaruh terhadap diameter zona hambat pertumbuhan bakteri S. aureus yang terbentuk. Semakin tinggi konsentrasi ekstrak etanol daun jambu biji lokal semakin besar pula diameter zona hambat terhadap pertumbuhan bakteri $S$. aureus. Untuk membuktikan pengaruh perbedaan dari setiap konsentrasi tersebut dilakukan uji statistik menggunakan uji analisis sidik ragam.

Berdasarkan Analisis Sidik Ragam, diketahui bahwa ekstrak etanol daun jambu biji lokal $F_{\text {hitung }}$ $(629,75)$ lebih besar dari $\mathrm{F}_{\text {tabel }}(0,01)$ dengan taraf nyata $(\alpha) 1 \%$ sebesar 4,70 . Berdasarkan hasil tersebut konsentrasi ekstrak etanol jambu biji lokal yang berbeda berpengaruh sangat nyata terhadap diameter zona hambat pertumbuhan bakteri $S$. aureus yang terbentuk secara in vitro.

Perlakuan yang menghasilkan jumlah diameter zona hambat terbesar pada ekstrak etanol daun jambu biji lokal terhadap bakteri $B$. subtilis adalah perlakuan pada konsentrasi 60 $\mathrm{mg} / \mathrm{ml}$ dengan rata-rata diameter $23,5 \mathrm{~mm}$. Rataan umum diameter yang terbentuk dari ekstrak etanol daun jambu biji lokal adalah 15,7.

Untuk membuktikan pengaruh perbedaan dari setiap konsentrasi tersebut dilakukan uji statistik dengan menggunakan Uji Analisis Sidik Ragam. Berdasarkan Analisis Sidik Ragam, diketahui bahwa hasil analisis pada ekstrak
p-ISSN 1907-3089, e-ISSN2651-5869

https://journal.uniku.ac.id/index.php/quagga

etanol daun jambu biji lokal $F_{\text {hitung }}(1073,50)$ lebih besar dari $\mathrm{F}_{\text {tabel }}(0,01)$ dengan taraf nyata $(\alpha)$ $1 \%$ sebesar 4,70. Berdasarkan hasil tersebut konsentrasi ekstrak etanol jambu biji lokal yang berbeda berpengaruh sangat nyata terhadap diameter zona hambat pertumbuhan bakteri $B$. subtilis yang terbentuk secara in vitro.

Hasil diameter zona hambat uji antibakteri ekstrak etanol terhadap bakteri $B$. subtilis dapat dilihat pada Tabel 2 .

Tabel 2. Diameter zona hambat uji antibakteri ekstrak daun Jambu Biji Lokal terhadap bakteri

$$
\text { B. subtilis }
$$

\begin{tabular}{ccccccc}
\hline & $(\mathrm{K})$ & \multicolumn{5}{c}{ Jambu Biji } \\
\cline { 3 - 7 } $\mathrm{T}$ & $\mathrm{mg} / \mathrm{m}$ & \multicolumn{5}{c}{ Diameter Zona Hambat (mm) } \\
\cline { 3 - 7 } & 1 & $\mathrm{U} 1$ & $\mathrm{U} 2$ & $\mathrm{U} 3$ & $\mathrm{JP}$ & $\mathrm{RP}$ \\
\hline $\mathrm{A}$ & 5 & 0 & 0 & 0 & 0 & 0 \\
\hline $\mathrm{B}$ & 10 & 10,7 & 9,7 & 10,2 & 30,6 & 10,2 \\
\hline $\mathrm{C}$ & 20 & 17,4 & 17,4 & 17,4 & 52,2 & 17,4 \\
\hline $\mathrm{D}$ & 30 & 17,6 & 18,3 & 18,3 & 54,2 & 18,1 \\
\hline $\mathrm{E}$ & 40 & 20,1 & 19,6 & 19,9 & 59,6 & 19,9 \\
\hline $\mathrm{F}$ & 50 & 21,4 & 19,8 & 20,3 & 61,5 & 20,5 \\
\hline $\mathrm{G}$ & 60 & 23,9 & 23,3 & 23,3 & 70,5 & 23,5 \\
\hline \multicolumn{7}{c}{$\mathrm{JU}$} \\
\hline
\end{tabular}

Flavonoid adalah suatu kelompok senyawa fenol yang terbanyak terdapat di alam. Prinsip kerja flavonoid sama dengan alkaloid yaitu dengan merusak dinding sel, hanya saja caranya yang berbeda, senyawa flavonoid merusak sel bakteri memanfaatkan perbedaan kepolaran antara lipid penyusun sel bakteri dengan gugus alkohol pada senyawa flavonoid.senyawa alkaloid memanfaatkan sifat reaktif gugus basa untuk bereaksi dengan gugus asam amino pada sel bakteri (Cowan, 1999). Flavonoid juga dapat membentuk kompleks dengan protein ekstraseluler dan terlarut dengan dinding mikroba. Kemungkinan lain adalah flavonoid berperan secara langsung dengan mengganggu fungsi sel mikroorganisma dan penghambatan siklus sel mikroba (Rattanachaikunsopon, 2010).

Alkaloid memiliki efek farmakologi pada manusia dan hewan sebagai zat antibakteri. Hal ini disebabkan karena alkaloid mempunyai kemampuan dalam menghambat kerja enzim untuk mensintesis protein bakteri. Penghambatan kerja enzim ini dapat mengakibatkan metabolisme bakteri terganggu (Ogbuagu, 2008). Alkaloid dapat juga merusak komponen penyusun peptidoglikan pada sel bakteri, sehingga lapisan dinding sel tidak terbentuk secara utuh dan menyebabkan kematian pada sel bakteri. Hal ini disebabkan alkaloid bersifat 
Quagga: Jurnal Pendidikan dan Biologi

Volume 10, Nomor 2, Juli 2018

hidfofilik, sehingga dengan mudah berdifusi menembus lapisan peptidoglikan dinding sel bakteri yang menyebabkan biosintesis dinding sel bakteri terganggu (Lamothe et al., 2009). Kemampuan inilah yang menyebabkan alkaloid mampu menghambat pertumbuhan bakteri Gram positif dan bakteri Gram negatif.

Polifenol mempunyai peran antara lain sebagai antibakteri dengan cara menghambat pertumbuhan bakteri patogen dalam saluran pencernaan. Hal ini sesuai dengan penelitian yang dilakukan oleh Alberto et al. (2006) mekanisme penghambatan anti bakteri polifenol yaitu dengan cara mengganggu pembentukkan dinding sel (Kunaepah, 2008). Terjadinya akumulasi senyawa antibakteri dipengaruhi oleh bentuk yang tidak terdisosiasi. Pada konsentrasi rendah, molekul fenol lebih hidrofobik, dapat mengikat daerah hidrofobik membran protein dan dapat melarut pada fase lipid dari membran bakteri. Polifenol dapat pula bereaksi dengan membran sel. Komponen bioaktif fenol dapat mengakibatkan lisis membran sel dan menyebabkan denaturasi protein, menghambat pembentukan protein sitoplasma dan asam nukleat serta menghambat ikatan ATP-ase pada membran sel (Kunaepah, 2008).

Mekanisme tanin sebagai antibakteri adalah mematikan bakteri dengan cara mengkoagulasi protoplasma bakteri sehingga terbentuk ikatan yang stabil dengan protein bakteri di dalam saluran pencernaan (Robinson, 1995; Wiryawan et al., 2000). Tanin dapat membentuk ikatan hidrogen dengan protein yang terdapat dalam sel bakteri, jika terbentuk ikatan hidrogen memungkinkan protein akan terdenaturasi akibatnya metabolisme bakteri menjadi terganggu (Makkar, 1991).

\section{SIMPULAN}

Diameter zona hambat terbesar ekstrak etanol daun jambu biji lokal terhadap pertumbuhan bakteri $S$. aureus adalah konsentrasi $50 \mathrm{mg} / \mathrm{ml}$ dengan rata-rata diameter $18,5 \mathrm{~mm}$, sedang diameter zona hambat terbesar ekstrak etanol daun jambu biji lokal terhadap pertumbuhan bakteri $B$. subtilis adalah konsentrasi $60 \mathrm{mg} / \mathrm{ml}$ dengan rata-rata diameter $23,5 \mathrm{~mm}$.

\section{REFERENSI}

Adnyana, IK, E Yulinah, JI Sigit, N Fisheri, M Insanu. 2004. Efek Ekstrak Daun Jambu Biji Daging Buah Putih dan Biji Daging Merah sebagai Antidiare. Institut Teknologi Bandung. Bandung
p-ISSN 1907-3089, e-ISSN2651-5869

https://journal.uniku.ac.id/index.php/quagga

Cowan, MM. 1999. Plant Products as Antimicrobial Agents. American Society for Microbiology. 12: 564-582

Gomez, KA. 1995. Prosedur Statistic untuk Penelitian Pertanian. Universitas Indonesia Press. Jakarta

Hembing, W. 1992. Tanaman Berkhasiat Obat di Indonesia Jiiid 2. Pustaka Kartini. Jakarta

Kunaepah, Uun. 2008. Pengaruh Lama Fermentasi Dan Konsentrasi Glukosa Terhadap Aktivitas Antibakteri, Polifenol Total Dan Mutu Kimia Kefir Susu Acang Merah. Tesis. Program Pascasarjana Universitas Diponegoro. Semarang

Lanawati, F. 2003. Aktvitas Antimikroba Ekstrak Daun Jambu Biji dari Beberapa Kultivar terhadap Staphylococcus aureus ATCC 25923 dengan "hole-plate diffusion method". Berk Penel Hayati. 9: 49-51

Lamothe, RG. 2009. Plant Antimicrobial Agents and their Effects on Plant and Human Pathogens. Int. J. Mol. Sci. 10: 34003419.

Makkar H.P.S. 2003. Effects and fate of tannins in ruminant animals, adaptation to tannins, and strategies to overcome detrimental effects of feeding tannin-rich feeds, Animal Production and Health Section, Joint FAO/IAEA Division. International Atomic Energy Agency. Vienna, Austria.

Mittal, P, V Gupta, G Kaur, AK Gaug, A Singh. 2010. Phytochemistry and Pharmacological Activities of Psidium guajava. IJPSR. 1: 9-19

Nisha, K, M Darshana, G Madhu, MK Bhupendra. 2011. GC-MS Analysis and Antimicrobial Activity of Psidium guajava (Leaves) Grown in Malva Region of India. IJDDR.3:1-9 
Quagga: Jurnal Pendidikan dan Biologi

Volume 10, Nomor 2, Juli 2018
p-ISSN 1907-3089, e-ISSN2651-5869

https://journal.uniku.ac.id/index.php/quagga

Ogbuagu MN. 2008. The nutritive and antinutritive composition of Calabash. Int. J. Mol. Sci. 10: 3400-3419

Rattanachaikunsopon, Pongsak. 2010. Contents and Antibacterial Activity Of Flavonoids Extracted From Leaves of Psidium guajava. Journal of Medicinal Plants Research. 4:393-396

Robinson, T. 1995. Kandungan Organik Tumbuhan Tinggi . Edisi ke-6. Terjemahan: K. Padmawinata. ITB-Press, Bandung.

Tjaniadi P, M Lesmana, D Subekti. Antimicrobial Resistance of Bacterial Pathogens Associated with Diarrheal Patiens in Indonesia. Am J Trop Med Hyg 2003; 68: 666-10.

Wiryawan, K. G, B. Tangendjaja, Suryahadi. 2000. Tannin Degrading Bacteria from Indonesian Ruminants. In : J. D. Brooker (Editor). Tannins in Livestock and Human Nutrition. ACIAR Procedings, 92: $123-132$ 